\title{
PERSEPSI MASYARAKAT MENGENAL PENGEMBANGAN EKOWISATA HUTAN MANGROVE DI DESA PASIR KECAMATAN MEMPAWAH HILIR
}

\author{
Norsidi $^{*}$, Suherdiyanto², Herly Yosi Manu ${ }^{3}$, \\ 1,2,3Program Studi Pendidikan Geografi, Fakultas Ilmu Pendidikan dan Pengetahuan Sosial, IKIP PGRI Pontianak, Pontianak, Indonesia \\ *Email Koresponden: habibisukma1991@gmail.com
}

Diterima: 04-04-2021, Revisi: 14-05-2021, Disetujui: 22-06-2021

(C)2021 Program Studi Pendidikan Geografi, FISE, Universitas Hamzanwadi

\begin{abstract}
Abstrak Tujuan penelitian ini adalah untuk memperoleh informasi tentang persepsi masyarakat mengenal pengembangan ekowisata hutan mangrove di Desa Pasir Kecamatan Mempawah Hilir Kabupaten Mempawah. Metode penelitian yang digunakan adalah metode survei. informasi dikumpulkan dari responden dengan menggunakan kuesioner. Teknik analisis data yang digunakan menggunakan statistik sederhana menggunakan distribusi frekuensi. Hasil penelitian menunjukkan bahwa: 1) persepsi masyarakat terhadap keberadaan ekowisata hutan mangrove di Desa Pasir Kecamatan Mempawah Hilir Kabupaten Mempawah adalah rata-rata nilai 91,57\% dengan kategori sangat baik; 2) persepsi masyarakat terhadap manfaat ekowisata hutan mangrove di Desa Pasir Kecamatan Mempawah Hilir Kabupaten Mempawah adalah rata-rata nilai 88,23 \% kategori baik; dan 3) persepsi masyarakat terhadap kebersihan ekowisata hutan mangrove di Desa Pasir Kecamatan Mempawah Hilir Kabupaten Mempawah adalah nilai rata-rata 84,86 \% cukup.
\end{abstract}

Kata kunci: persepsi masyarakat, ekowisata, hutan mangrove

\begin{abstract}
The purpose of this study was to get information about the perceptions and attitudes of the community towards the development of mangrove forest ecotourism in Pasir Village, Mempawah Hilir District, Mempawah Regency. The research method used is a survey method. In survey research, it collected information from respondents using a questionnaire. The data analysis technique used is statistical techniques, with the formula for the percentage. Based on the research results it concluded: 1) The community's perception of the existence of mangrove forest ecotourism in Pasir Village, Mempawah Hilir District, Mempawah Regency is an average value of $91.57 \%$ with a very good category; 2) The public perception of the benefits of mangrove forest ecotourism in Pasir Village, Mempawah Hilir District, Mempawah Regency, was an average value of $88.23 \%$ in good category; 3) the public perception of the cleanliness of mangrove forest ecotourism in Pasir Village, Mempawah Hilir District, Mempawah Regency, an average value of $84.86 \%$ was sufficient.
\end{abstract}

Keywords: community perceptions, ecotourism, mangrove forest

\section{PENDAHULUAN}

Hutan merupakan bagian dari ekosistem yang memiliki banyak manfaat peranan penting dalam menyangga sistem kehidupan. Hutan adalah suatu kumpulan bidang-bidang lahan yang ditumbuhi (memilki) atau akan di tumbuhi tumbuhan pohon dan dikelola sebagai satu kesatuan yang utuh untuk mencapai tujuan pemilik lahan berupa kayu atau hasil-hasil lain yang berhubungan (Davis and Jhonson, 1987, dalam Suhendang, 2002). Keberadaan hutan memiliki banyak manfaat besar bagi makhluk hidup yang diperoleh melalui fungsinya baik sebagai penyedia sumber daya air untuk manusia dan lingkungan, pemasok oksigen di udara, kemampuan penyerapan karbon, penyedia jasa wisata lingkungan untuk kesejahteraan ekonomi manusia dan menstabilkan iklim dunia secara global.

Perlu dikembangkan potensi sumber daya alam hayati dan ekosistem tersebut, agar bisa dimanfaatkan secara luas untuk kepentingan dan kesejahteraan masyarakat tanpa mengurangi upaya konservasi sehingga tetap tercapai keseimbangan antara perlindungan, pengawetan dan pemanfaatan yang lestari yang berkelanjutan. Potensi yang bisa dikembangkan melalui keberadaan hutan yakni 
pemanfaatan jasa lingkungan. ESCAP (2009) dalam Idrus, Ismail, \& Ekayani (2016) menyatakan bahwa yang menjadi tolak ukur keberhasilan dalam pelaksanaan pembayaran jasa lingkungan (PJL) adalah dengan menetapkan nilai ekonomi jasa lingkungan, mendapat dukungan dan keikutsertaan masyarakat, serta adanya penetapan kelembagaan.

Pemanfaatan jasa lingkungan untuk kepentingan pengembangan wisata alam, harus memperhatikan prinsip-prinsip arif lingkungan yakni konservasi, edukasi, ekonomi, rekreasi dan partisipasi masyarakat. Ekowisata adalah suatu bentuk perjalanan wisata ke area alami yang dilakukan dengan tujuan mengkonservasi lingkungan dan melestarikan kehidupan dan kesejahteraan penduduk setempat (Edi \& Nur, 2006). Jasa lingkungan bisa terwujud apabila didukung oleh ekosistem alam yang baik sehingga memiliki nilai dan manfaat besar, agar dapat dirasakan secara langsung maupun tidak langsung dengan pihak terkait (stakeholder) dalam rangka memelihara dan meningkatkan kualitas lingkungan dan kehidupan masyarakat untuk mewujudkan pengelolaan ekosistem secara berkelanjutan.

Program ekowisata dengan pemanfaatan jasa lingkungan menitikberatkan ada keberlangsungan ekologi serta keberlanjutan ekonomi untuk tingkat penerimaan dalam kehidupan sosial masyarakat. Keberlangsungan secara ekologi berpedoman pada pengembangan yang berkelanjutan dengan memperhatikan kelestarian dan perlindungan keanekaragaman hayati. Permanfaatan kawasan mangrove untuk dikembangkan menjadi salah satu kawasan ekowisata merupakan alternatif pemanfaatan yang sangat rasional diterapkan di kawasan pesisir karena dapat memberi manfaat ekonomis dan jasa lingkungan tanpa mengeksploitasi mangrove. Pemanfaatan jasa lingkungan berupa ekowisata akan mendorong upaya konservasi ekosistem mangrove sebagai daerah penyangga kawasan konservasi (Kusmana \& Istomo, 1993). Keberlangsungan secara ekonomi untuk peningkatan kesejahteraan masyarakat dengan tetap berdaulat dalam memanfaatkan beragam hasil produk melalui jasa lingkungan. Strategi pengembangan ekowisata untuk memenuhi kebutuhan kawasan juga dapat dirumuskan melalui elaborasi masingmasing komponen ekowisata (Ria et al. 2021).

Keberadaan ekowisata membuka peluang orang untuk berinvestasi dalam menambah devisa negara. Eksistensi ekowisata harus menunjukkan proses perubahan kehidupan tatanan sosial masyarakat baik dalam kerjasama dan persaingan antara pelaku pariwisata. Pengembangan kawasan ekowisata hutan mangrove secara berkelanjutan menjadi salah satu alternatif untuk menanggulangi terjadinya degradasi dimasa yang akan mendatang. Ekowisata adalah perjalanan bertanggung jawab secara lingkungan dan kunjungan ke kawasan alami, da- lam rangka menikmati dan menghargai alam (serta semua ciri-ciri budaya masa lalu dan masa kini) untuk mempromosikan konservasi, memiliki dampak kecil dan mendorong pelibatan sosial ekonomi masyarakat lokal secara aktif sebagai penerima manfaat (Ria et al. 2021).

Salah satu objek ekowisata yang saat ini banyak menarik perhatian masyarakat adalah pengembangan ekowisata mangrove. Hutan mangrove merupakan komunitas vegetasi pantai tropis, yang didominasi oleh beberapa spesies pohon mangrove yang mampu tumbuh dan berkembang pada daerah pasang surut pantai berlumpur (Ilham, et al., 2016). Mangrove adalah sebutan untuk komunitas tumbuhan yang hidup di daerah pantai yang memiliki adaptasi khusus dengan lingkunganya (Shinta, 2017). Komonitas vegetasi ini umumnya tumbuh pada daerah yang cukup mendapat aliran air dan terlindung dari gelombang besar dan arus pasang surut yang kuat, karena itu hutan mangrove banyak ditemukan di pantai-pantai teluk yang dangkal, estuaria,delta dan daerah pantai yang terlindung (Keninish, 1990).

Keberadaan hutan mangrove bagi masyarakat pesisir pantai dapat mendukung kesejahteraan peningkatan nilai ekonomis yang dapat dimanfaatkan secara langsung misalnya batang, akar, daun dan buah. Pembanguan pariwisata yang memiliki nlai ekonomis harus diarahkan pada pemanfaatan sumber daya alam (Nining \& Susmala, 2018). Salah satu hutan mangrove yang berpotensi memiliki nilai ekonomis berada di Desa Pasir Kecamatan Mempawah Kabupaten Mempawah Provinsi Kalimantan Barat. Hutan mangrove Desa Pasir Kecamatan Mempawah secara tidak langsung mendukung keberadaan kehidupan ekosistem lain di sekitarnya seperti perikanan pantai dan terumbu karang. Keberadaan hutan mangrove juga memiliki nilai ekologis sebagai pelindung pantai untuk mencegah abrasi dari hempasan gelombang laut. Keberadaan hutan mangrove amatlah penting dikarenakan 
mempunyai peran ganda disamping memiliki potensi ekologis dan juga memberikan manfaat ekonomi bagi kesejahteraan masyarakat disekitarnya (Risma, 2014).

Di kawasan pesisir pantai Desa Pasir Kecamatan Mempawah sudah terjadi abrasi pantai sebagai dampak dari gelombang dan pemanfaatan mangrove yang tidak memperhatikan kelestarian secara arif lingkungan. Keseimbangan ekologi lingkungan perairan pantai akan tetap terjaga apabila keberadaan mangrove dipertahankan karena mangrove dapat berfungsi sebagai biofilter, agen pengikat dan perangkap polusi (Risma, 2014). Secara global deforestasi mangrove yang telah terjadi di Kabupaten Mempawah didapatkan dari hasil interprestasi menggunakan citra satelit Landsat 5 yang direkam pada tanggal 29 Juni 1989 dan Landsat 8 yang direkam pada tanggal 6 Februari 2014. Hasilnya memperlihatkan telah terjadi deforestasi ekosistem mangrove di Kabupaten Mempawah seluas 250,88 ha, reforestasi ekosistem mangrove seluas 174, 14 ha dan 565,18 ha masihalami (Khairudin, 2016).

Merujuk pada berbagai penelitian yang pernah dilakukan mengenai keberadaan hutan mangrove sebelumnya, sebagian besar hanya berfokus pada sisi peluang nilai ekonomi bagi masyarakat pesisir pantai untuk mendukung kesejahteraan. Penelitian ini dilakukan untuk mendeskripsikan persepsi masyarakat yang ada kawasan pesisir pantai Desa Pasir Kecamatan Mempawah terhadap pengembangan ekowisata hutan mangrove telah dilakukan secara arif lingkungan. Perlu peningkatan kesadaran masyarakat sekitar untuk menjaga lingkungan hutan mangrove agar tetap lestari.

\section{METODE PENELITIAN}

Metode penelitian yang digunakan adalah metode survei. Survei merupakan sebuah metode riset yang pengumpulan datanya melalui kuisioner (Singarimbun \& Sofian Effendi, 2002.) dengan tujuan untuk memperoleh informasi tentang sejumlah responden yang dianggap mewakili populasi tertentu (Kriyantono, 2008). Jenis penelitian ini merupakan penelitian deskriptif dengan pendekatan kuantitatif melalui pengukuran secara cermat tentang fenomena-fenomena sosial tertentu (Singarimbun \& Sofian Effendi, 2002.). Indikator yang digunakan adalah elemen keberhasilan program yang terdiri dari konflik, durasi, kesukaan, konsistensi, energi, timing, dan tren.

Jenis penelitian deskriptif bertujuan untuk membuat deskripsi secara sistematis, faktual dan akurat tentang fakta-fakta dan sifat-sifat populasi atau objek tertentu (Kriyantono, 2008). Pendekatan kuantitatif adalah riset yang menggambarkan atau menjelaskan suatu masalah yang hasilnya dapat digeneralisasikan. Dengan demikian tidak terlalu mementingkan kedalaman data atau analisis. Peneliti lebih mementingkan aspek keleluasaan data sehingga data atau hasil riset dianggap merupakan representasi dari seluruh populasi (Kriyantono, 2008). Penelitian ini hanya mengoperasikan satu variabel saja yaitu persepsi masyarakat mengenal pengembangan ekowisata hutan mangrove.

Setiap pelaksanaan penelitian tidak terlepas dari objek dan subjek penelitian. Melalui objek penelitian tersebut akan diperoleh variabel-variabel yang menjadi permasalahan sekaligus merupakan sumber data yang akan diteliti. Objek yang ditetapkan untuk diteliti adalah populasi. Sampel dalam penelitian ini adalah sebagian dari populasi. Teknik pengambilan sampel yang digunakan dalam penelitian ini adalah menggunakan purporsive sampling yaitu pengambilan sampel dengan pertimbangan tertentu. Pemilihan kelompok sabjek dalam purporsive sampling didasarkan atas ciri-ciri tertentu, yang dipandang mempunyai sangkut-paut dengan ciri-ciri populasi. Oleh sebab itu, pertimbangan yang dijadikan dasar dalam pengambilan sampel pada penelitian ini adalah masyarakat di sekitar lokasi wisata hutan mangrove yang berjumlah kurang lebih 100 orang.

Teknik analisis data yang digunakan peneliti untuk Sub masalah 1, 2 dan 3 akan dijawab dengan menggunakan teknik statistik, dengan rumusan persentase (Anas, 2012):

$$
\mathrm{X} \%=\frac{\boldsymbol{n}}{\boldsymbol{N}} \mathrm{x} 100 \%
$$

Keterangan:

$\mathrm{X} \% \quad=$ persentase yang dicari

$\mathrm{n} \quad=$ jumlah skor aktual aspek variable

$\mathrm{N} \quad=$ jumlah skor maksimal ideal tiap aspek variabel

Rumus Interval

$$
\text { Interval }=\frac{\text { Rentang }}{\text { Jumlah Kelas }}
$$


Rentang $=$ skor tertinggi - skor terendah

Jumlah kelas $=1+3,3 \log (\mathrm{N})$

\section{TEMUAN DAN PEMBAHASAN}

\section{Persepsi Masyarakat terhadap Pengelolaan Ekowisata Hutan Mangrove di Desa Pasir Kecamatan Mempawah Hilir Kabupaten Mempawah}

Data ini merupakan hasil dari jawaban responden melalui kuesioner tentang persepsi masyarakat terhadap pengelolaan ekowisata hutan mangrove di Desa Pasir Kecamatan Mempawah Hilir Kabupaten Mempawah. Adapun hasil persepsi masyarakat terhadap pengelolaan ekowisata hutan mangrove di Desa Pasir Kecamatan Mempawah Hilir Kabupaten Mempawah disajikan pada gambar sebagai berikut:

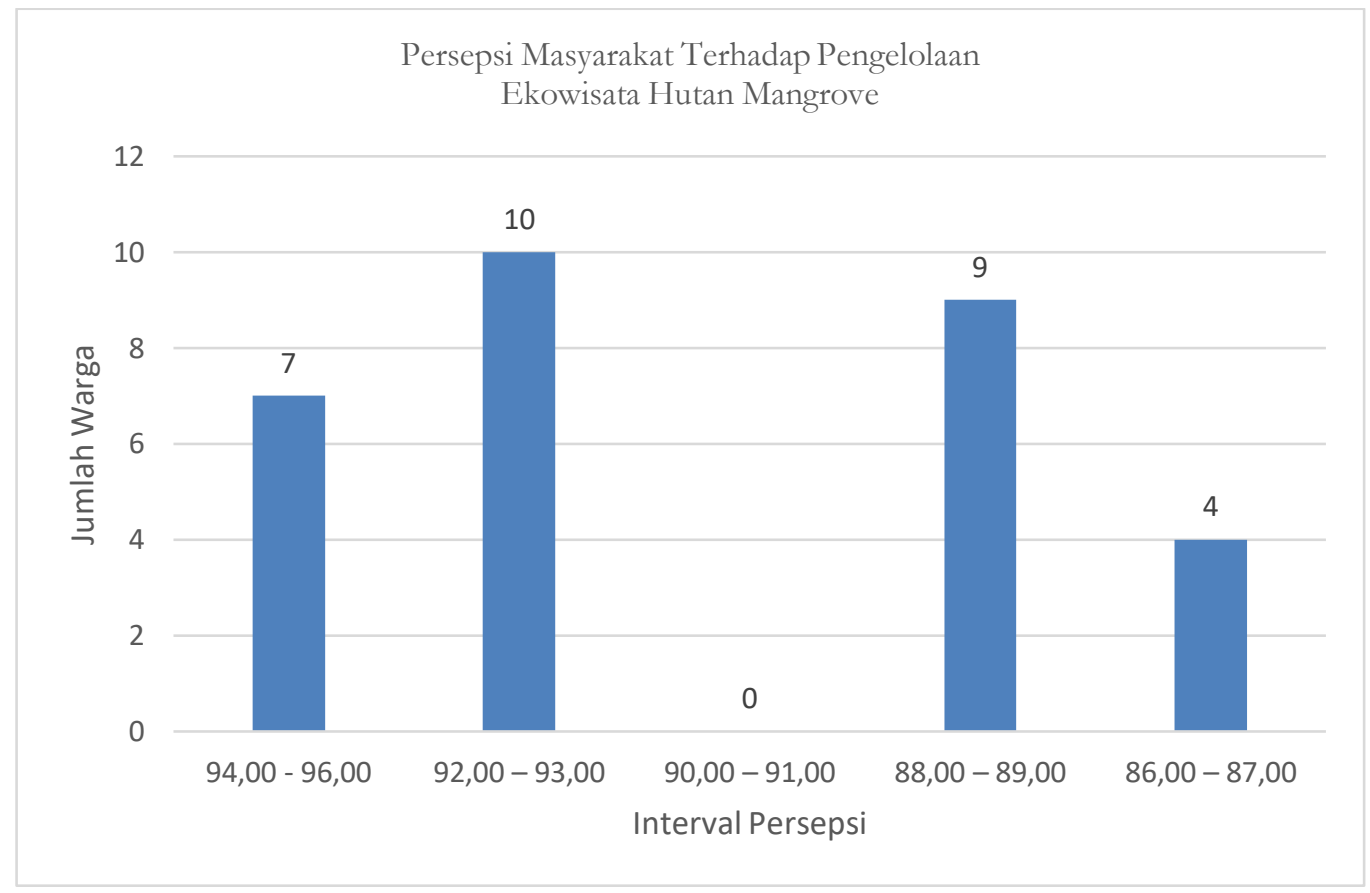

Gambar 1. Persentase Tentang Pengelolaan Ekowisata Hutan Mangrove (Sumber: Hasil Analisis Peneliti, 2021)

Dari hasil yang sudah didapat bahwa persepsi masyarakat terhadap pengelolaan ekowisata hutan mangrove sangat baik karena dilihat dari fasilitas yang ada dan dijaga dengan baik oleh masyarakat tersebut. Masyarakat Desa Pasir Kecamatan Mempawah Hilir Kabupaten Mempawah melakukan pendekatan kelembagaan dalam pengelolaan ekositem mangrove melalui sebuah komunitas dalam hal ini Mempawah Mangrove Conservation (MMC) berpartisipasi sebagai Fasilitator pendamping masyarakat. Peran Mempawah Mangrove Conservation (MMC) untuk melestarikan ekositem hutan mangrove sebagai upaya penanggulangan abrasi pantai di pesisir Desa Pasir Kecamatan Mempawah Hilir Kabupaten Mempawah. Gerakan kepedulian lingkungan yang dilakukan Mempawah Mangrove Conservation (MMC) selalu didukung oleh berbagai pihak, mulai dari instansi pemerintah, perusahaan swasta dan masyarakat sekitar pesisir. Urgensi pengendalian pemanfaatan ruang kawasan pesisir Desa Pasir Kecamatan Mempawah Hilir Kabupaten Mempawah sangat diperlukan sebagai upaya dalam menjaga stabilitas lingkungan dari kepentingan antara kebutuhan pelestarian lingkungan hidup dengan kebutuhan peningkatan perekonomian daerah. Mengingat pentingnya peranan ekosistem hutan mangrove dalam keseimbangan ekosistem pesisir, maka diperlukan dorongan untuk mengelola dan memanfaatkan hasil hutan mangrove dengan tetap menjaga kelestarian ekosistem mangrove itu sendiri (Komang et al., 2019). Upaya peningkatan kesadaran kepada masyarakat melalui berbagai program kegiatan sekitar kawasan hutan mangrove agar menanggap serius pentingnya pelestarian kawasan hutan mangrove mengingat kerusakan hutan mangrove juga disebabkan oleh perilaku manusia. 
Rutinitas kegiatan penanaman oleh komunitas Mempawah Mangrove Conservation (MMC) tergolong aforestasi dengan melakukan pembentukan hutan atau tegakkan pepohonan di area yang sebelumnya bukan merupakan hutan. Demikian juga dengan Harahab (2009) menyatakan bahwa adanya kelembagaan pengelolaan yang melibatkan semua elemen stakeholder biasa mencegah terjadinya kerusakan mangrove. Peranan Lembaga Swadaya Masyarakat merupakan salah satu stakeholder penting dalam pengelolaan kawasan hutan (Sihite, 2005).

\section{Persepsi Masyarakat Terhadap Manfaat Keberadaan Ekowisata Hutan Mangrove di Desa Pasir Kecamatan Mempawah Hilir Kabupaten Mempawah}

Data ini merupakan hasil dari angket tentang persepsi masyarakat terhadap manfaat keberadaan ekowisata hutan mangrove di Desa Pasir Kecamatan Mempawah Hilir Kabupaten Mempawah. Adapun hasil persepsi masyarakat terhadap manfaat keberadaan ekowisata hutan mangrove di Desa Pasir Kecamatan Mempawah Hilir Kabupaten Mempawah disajikan pada gambar sebagai berikut:

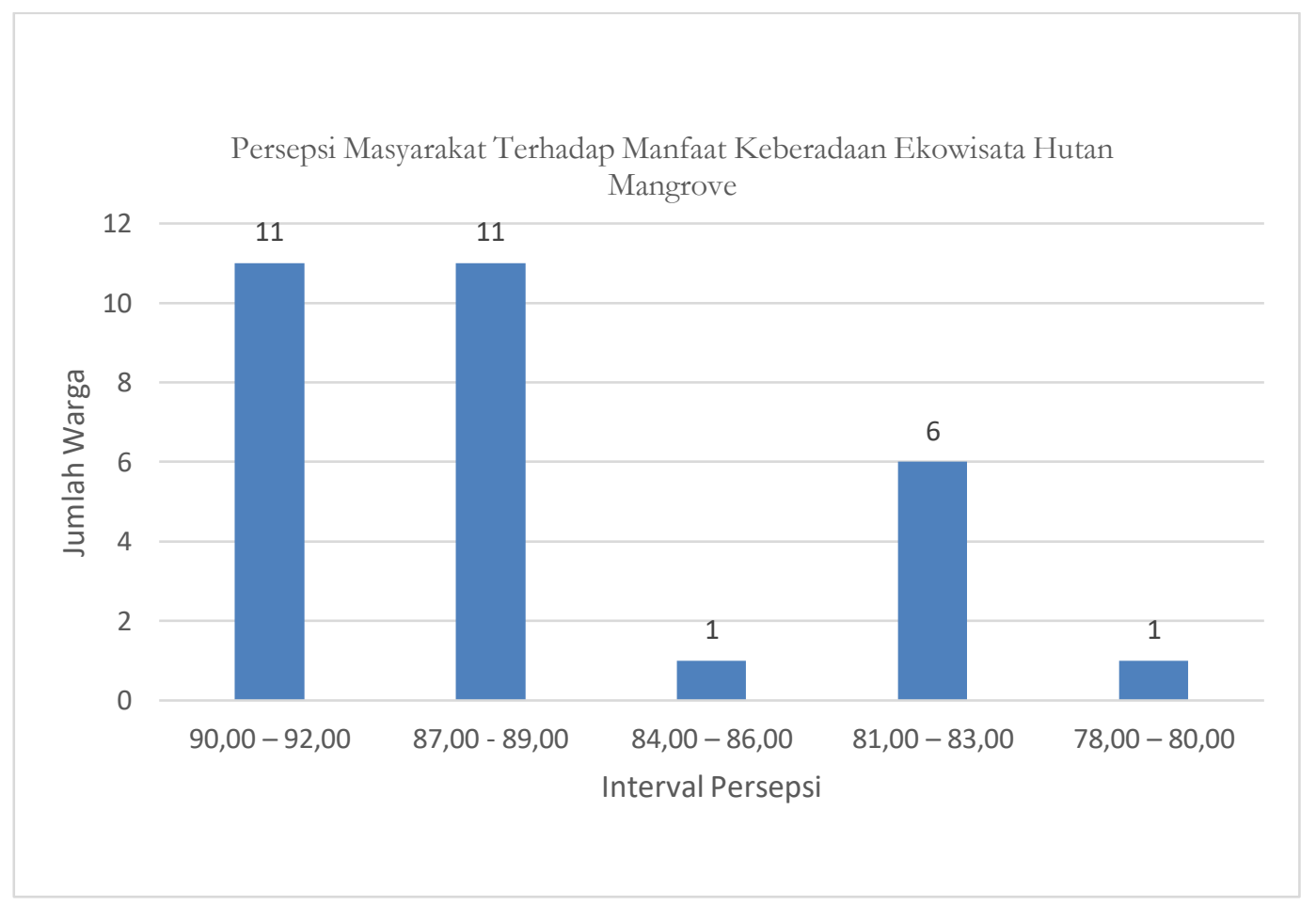

Gambar 2. Persepsi Masyarakat Terhadap Manfaat Keberadaan Ekowisata Hutan Mangrove (Sumbar: Hasil Analisis Peneliti, 2021)

Dari hasil yang diperoleh dari responden bahwa keberadaan ekowisata hutan mangrove memiliki banyak manfaat bagi masyarakat sekitar. Keberadaan hutan mangrove memiliki manfaat nilai ekonomis bagi masyarakat pesisir pantai untuk mendukung kesejahteraan hidup yang dapat diambil secara langsung misalnya batang, akar, daun dan buah. Sebelum masyarakat beranggapan bahwa pemanfaatan hutan mangrove selama ini hanya bisa dimanfaatkan untuk keperluan kayu bakar dengan menebang pohonnya. Pemanfaatan hasil hutan kayu diantaranya sebagai bahan bangunan, kayu bakar, atau arang. (Komang et al., 2019). Masyarakat Desa Pasir Kecamatan Mempawah Hilir Kabupaten Mempawah sadar karena hutan mangrove memiliki manfaat nyata yang dirasakan. Keberadaan hutan mangrove dipesisir pantai juga mampu untuk mewujudkan kondisi sirkulasi udara yang baik. Hal ini dikarenakan hutan mangrove mampu menyerap karbon dan melepaskan oksigen yang dibutuhkan manusia dalam bernafas sehingga berefek pada kesehatan manusia yang dikarenakan udara yang bersih dan terhindar dari polusi (Dian et al., 2018). Selain itu juga kayu mangrove memiliki banyak keunggulan dibandingkan dengan kayu dari pohon lain, karena hutan mangrove dapat mengikat CO yang terdapat di atmosfer yang selanjutnya akan disimpan didalam kayu mangrove (Komang et al., 2019). 
Hutan Mangrove tersebut juga berfungsi sebagai sumber mata pencaharian nelayan, tempat rekreasi atau wisata alam, obyek pendidikan pelatihan dan pengembangan ilmu pengetahuan. Potensi lain yang bisa dikembangkan dari manfaat keberadaan hutan Desa Pasir Kecamatan Mempawah Hilir Kabupaten Mempawah bisa menjadi pelopor dengan pengembangan budi daya madu, kepiting, dan udang. Peluang untuk menindaklanjutinya sangat terbuka, jika masyarakat Desa Pasir Kecamatan Mempawah Hilir Kabupaten Mempawah fokus dan serius dengan eksplorasi dan edukasi sebagai bagian strategi utama. Upaya pengolahan hasil hutan mangrove agar bernilai ekonomi, perlu memperhatikan teknik pengolahannya, metode, pengemasan terhadap produk olahan, serta pemasaran yang tepat. Selain itu, pelatihan (training) terhadap SDM yang akan terlibat menjadi fokus utama dikarenakan dalam proses pengolahan tersebut dibutuhkan sebuah keahlian (skill) tertentu yang dapat mendukung keberhasilan produk mangrove itu sendiri (Komang et al., 2019).

Pada kawasan pesisir Desa Pasir Kecamatan Mempawah Hilir Kabupaten Mempawah bisa dikembangkan bibit-bibit terbaik untuk siap ditanam di kawasan konservasi dan ekowisata. Bibit hutan mangrove yang dikembangkan tersebut memberikan dua manfaat. Pertama, dengan bibit berkembang secara baik akan dapat memberikan keuntungan ekonomi bagi masyarakat dengan menjual bibit. Kedua sangat membantu untuk mengembang daerah konservasi di Mempawah Mangrove Park (MMP) yang saat ini sedang dikelola sebagai nilai ekologis sebagai pelindung pantai untuk mencegah abrasi dari hempasan gelombang laut. Daerah hutan mangrove juga bisa menjadi sarana edukasi, konservasi, pelestarian lingkungan dan penyelamatan daerah pantai (Muthmainnah et al., 2020).

Mangrove berperan penting dalam melindungi lingkungan, antara lain dari melindungi daratan dari abrasi, mengontrol intrusi air laut dan sebagai tempat berkembang biak biota laut seperti ikan dan kepiting (Komang et al., 2019). Fungsi hutan mangrove sebagai penyedia pakan (feeding ground) untuk berbagai jenis biota seperti jenis kepiting. Dengan adanya hutan mangrove yang tumbuh maka suplai makanan akan tersedia dengan berlimpah (Suwarsih, 2013). Adanya keterkaitan antara masyarakat dengan keberadaan hutan mangrove ini menimbulkan adanya persepsi masyarakat dalam upaya menjaga dan melestarikan keberadaan hutan mangrove sehingga ekosistem yang terdapat di hutan mangrove tersebut tetap terjaga (Kadhapi et al., 2015). Sepatutnya ekowisata layak untuk dikeloloa dan dikembangkan, agar keberlangsungan ekowisata akan tetap berlangsung dan tetap ada di masa yang akan datang (Safuridar \& Puti, 2020).

\section{Persepsi Masyarakat Terhadap Kebersihan Ekowisata Hutan Mangrove di Desa Pasir Kecamatan Mempawah Hilir Kabupaten Mempawah}

Data ini merupakan hasil dari angket tentang persepsi masyarakat terhadap kebersihan ekowisata hutan mangrove di Desa Pasir Kecamatan Mempawah Hilir Kabupaten Mempawah. Adapun hasil persepsi masyarakat terhadap kebersihan ekowisata hutan mangrove di Desa Pasir Kecamatan Mempawah Hilir Kabupaten Mempawah disajikan pada Gambar 3. Dari gambar diagram batang tersebut tersebut bahwa kebersihan hutan mangrove di Desa Pasir Kecamatan Mempawah Hilir Kabupaten Mempawah cukup. Selama ini masyarakat secara tidak langsung ikut berkontribusi pada kerusakan hutan mangrove salah satunya membuang sampah tidak pada tempatnya. Hubungan antara manusia dan lingungan dapat berdampak positif maupun negatif. Jika manusia mengelola dengan baik tentu ekosistem lingkungan sekitar akan tetap terjaga, namun apabila kesadaran tidak diterapkan hal ini tentu dapat berdampak buruk pada lingkungan yang juga dapat berimbas pada masyarakat itu sendiri (Dian et al., 2018). Perlu kesadaran Masyarakat sebagai kekuatan untuk menjaga kelestarian hutan mangrove. Masyarakat di Desa Pasir Kecamatan Mempawah Hilir Kabupaten Mempawah belum ikut serta semua mengkampanyekan penyelamatan dan pelestarian hutan mangrove. Untuk memiliki kualitas hidup tentu harus memiliki kehidupan dan keadaan sadar harus mendahului kualitas hidup, disini lingkungan yang baik tentu akan meningkatkan kualitas hidup yang masyarakatnya juga (Yati, 2014). Pemerintah dapat melakukan sosialisasi kepada masyarakat sekitar agar bisa bisa menjaga ekosistem mangrove (Ria et al., 2021). Perlu diberikan strategi pembinaan kepada masyarakat sebagai upaya untuk menumbuhkan dan meningkatkan kesadaran masyarakat akan arti dan nilai ekosistem mangrove, sehingga perlu dilestarikan (Bambang et al., 2018).

Upaya sosialisasi yang dilakukan selama ini, berkenaan pengetahuan dan pentingnya menjaga kelestarian suatu sumber daya alam hutan mangrove hanya ditunjukan kepada orang-orang dewasa 
belum menyentuh semua elemen lapisan masyarakat. Selain itu juga berkurangnya luasan hutan mangrove karena adanya perubahan tata guna dan fungsi lahan mangrove melalui berbagai macam aktivitas konversi lahan. Sebagian kawasan hutan mangrove di Desa Pasir Kecamatan Mempawah Hilir Kabupaten Mempawah di klaim oleh sebagian masyarakat sekitar sehingga pemerintah terbatas untuk menyediakan sarana dan prasarana tempat sampah yang memadai. Untuk mendukung kawasan hutan mangrove perlu Melakukan perbaikan infrastruktur penunjang ekowisata atau melengkapi infrastruktur pendukung kegiatan wisata alam, khususnya ekowisata, seperti jalan, jembatan, sarana kebersihan (Ria et al., 2021).

Hal ini sejalan dengan Dea (2016) perlunya fasilitas untuk memenuhi kebutuhan pengunjung seperti tempat duduk untuk bersantai dan penyedian tempat sampah agar pengunjung tidak membuang sampah bekas makanan di sembarang tempat sehingga kawasan hutan mangrove terlihat nyaman untuk dikunjungi. Lingkungan yang asri dan bebas sampah akan memberikan suasana nyaman, sehat dan akan mempengaruhi keberlangsungan hidup (Dian et al., 2018). Hal ini sejalan dengan pendapat Fauzi, (2012) yang menyatakan bahwa kelestarian hutan hanya dapat diwujudkan jika masih terdapat hubungan yang harmonis antara manusia dengan hutan dan menjunjung tinggi nilai-nilai budaya yang terkandung di dalamnya. Hal ini menjadikan peranan hutan mangrove pada sanitasi lingkungan terutama pada pengelolaan air dan limbah menjadi lebih terasa (Putra, 2014). Sanitasi lingkungan merupakan usaha yang sangat mendasar bagi terwujudnya lingkungan yang sehat. Kondisi sanitasi yang perlu diperhatikan adalah penyediaan air bersih, pembuangan kotoran manusia, pengelolaan sampah serta pengolahan limbah (Masayoe, 2016).

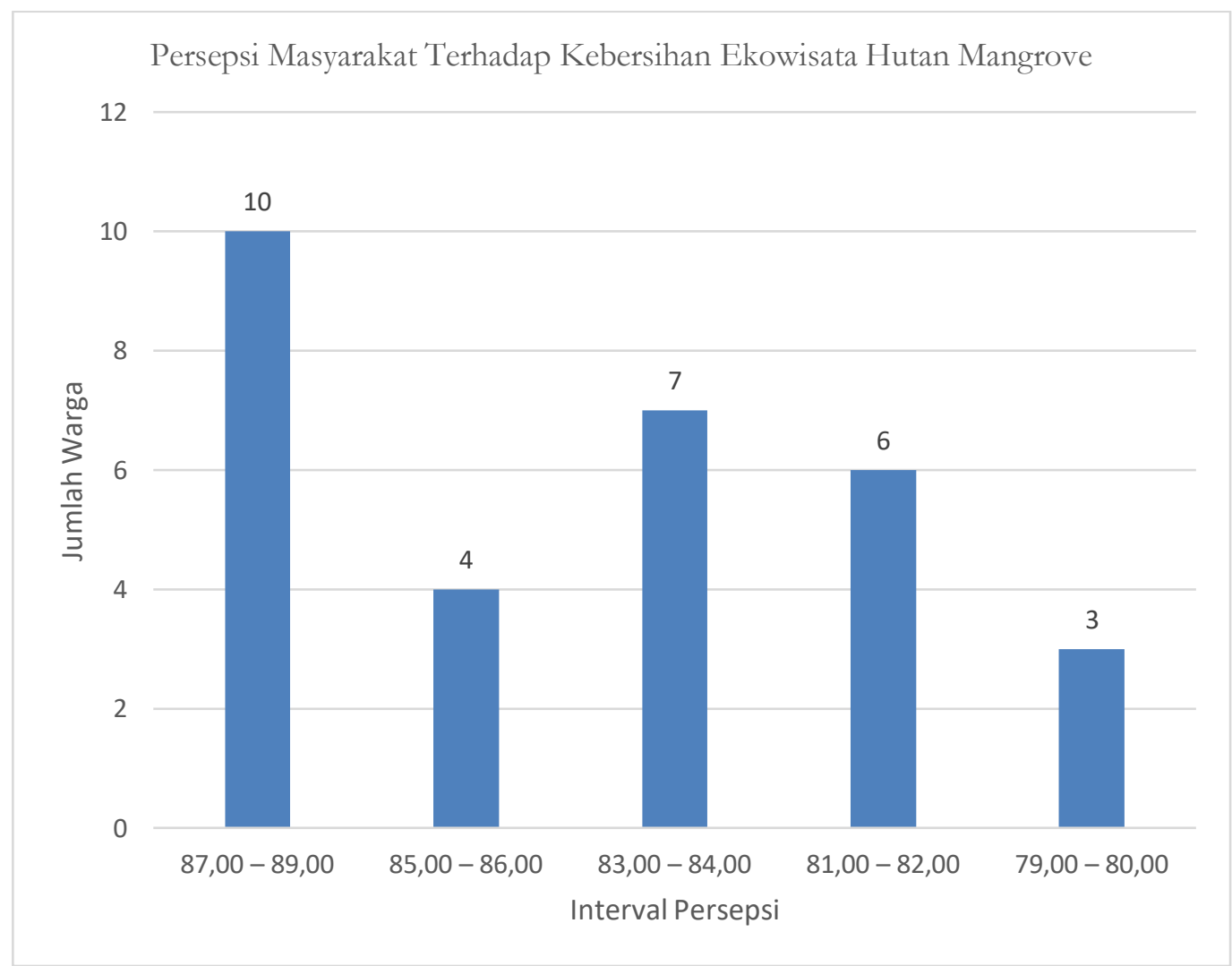

Gambar 3. Persentase Persepsi Masyarakat Terhadap Kebersihan Ekowisata Hutan Mangrove (Sumbar: Hasil Analisis Peneliti, 2021)

\section{SIMPULAN}

Berdasarkan hasil penelitian dapat disimpulkan sebagai berikut: (1) Persepsi masyarakat terhadap keberadaan ekowisata hutan mangrove di Desa Pasir Kecamatan Mempawah Hilir Kabupaten Mempawah adalah rata-rata nilai $91,57 \%$ dengan kategori sangat baik karena ada dukungan 
pengelolaan ekositem mangrove melalui sebuah komunitas dalam hal ini Mempawah Mangrove Conservation (MMC) berpartisipasi sebagai fasilitator pendamping masyarakat.; (2) Persepsi masyarakat terhadap manfaat ekowisata hutan mangrove di Desa Pasir Kecamatan Mempawah Hilir Kabupaten Mempawah adalah rata-rata nilai 88,23 \% kategori baik karena keberadaan hutan mangrove memiliki manfaat nilai ekonomis bagi masyarakat pesisir pantai untuk mendukung kesejahteraan hidup serta mampu untuk mewujudkan kondisi sirkulasi udara yang baik; (3) persepsi masyarakat terhadap kebersihan ekowisata hutan mangrove di Desa Pasir Kecamatan Mempawah Hilir Kabupaten Mempawah adalah nilai rata-rata 84,86 \% cukup karena lemahnya kesadaran masyarakat sekitar akan menjaga lingkungan hutan mangrove seperti membuang sampah di sekitar area hutan mangrove. Selama ini masyarakat secara tidak langsung ikut berkontribusi pada kerusakan hutan mangrove salah satunya membuang sampah tidak pada tempatnya.

\section{DAFTAR PUSTAKA}

Anas, S. (2012). Pengantar Evaluasi Pendidikan. Jakarta: Paja Grafindo.

Bambang, E. T., R., S., \& Ery, A. P. (2018). Peran Serta Masyarakat dan Kewenangan Pemerintah Dalam Konservasi Mangrove Sebagai Upaya Mencegah Rob dan Banjir Serta Sebagai Tempat Wisata. Masalah-Masalah Hukum, Jilid 47, 479-497.

Dea, J. (2016). Studi Tentang Pengawasan Hutan Mangrove Oleh Dinas Kehutanan di Kota Tarakan. Journal Pemerintahan Integratif, 155-165.

Dian, D. N., P, S. A., R, A. A., \& Jasmine, S. (2018). Sanitasi Lingkungan Dalam Menjaga Kualitas Hidup Pada Ekosistem Hutan Mangrove. Jurnal Psikologi, 48-60.

Edi, M., \& Nur, F. (2006). Konservasi Hutan Mangrove Sebagai Ekowisata. Jurnal Ilmiah Teknik Lingkungan, 11-18.

Fauzi. (2012). Pembangunan Hutan Berbasis Kehutanan Sosial. Semarang: Karya Putra.

Harahab, N. (2009). Pengaruh Ekosistem Hutan Mangrove Terhadap Produksi PerikananTangkap (Studi Kasus di KabupatenPasuruan Jawa Timur). Jurnal Perikanan, 124-130.

Idrus, S., Ismail, A., \& Ekayani, M. (2016). Potensi Pembayaran Jasa Lingkungan Hutan Mangrove di Kecamatan Jailolo Kabupaten Halmahera Barat. Jurnal Ilmu Pertanian Indonesia, 21(3), 195-202.

Ilham, Majid, Mimien, H. I., Fachur, R., Istamar, \& Syamsuri. (2016). Konservasi Hutan Mangrove di Pesisir Pantai Kota Ternate Terintegrasi Dengan Kurikulum Sekolah. Jurnal Bioedukasi, 488-196.

Kadhapi, M., Gusti, H., \& Zainal, S. (2015). Persepsi Masyarakat Desa Sungai Awan Kanan Terhadap Keberadaan Hutan Mangrove di Kawasan Pantai Air Mata Permai Kabupaten Ketapang. Jurnal Hutan Lestari, 108-116.

Keninish, M. (1990). Ekologi of Estuaries. Boca Raton Flodida: CRC.Press Inc.

Khairudin, B. (2016). Strategi Kebijakan Pengelolaan Ekosistem Mangrove Secara Terpadu dan Berkelanjutan di Kabupaten Pontianak Propinsi Kalimantan Barat. Bogor: Disertasi.

Komang, D. A., Pande, K. S., \& F. Maftukhakh, H. N. (2019). Peran Balai Pengelolaan Hutan Mangrove Wilayah I Bali Dalam Pengelolahan Hasil Hutan Mangrove Berbasis Pemberdayaan Masyarakat Lokal. Jurnal Sosial Ekonomi Pertanian, 331-339.

Kriyantono, R. (2008). Teknik Praktis Riset Komunikasi. Jakarta: Kencana Prenada Media Group.

Kusmana, C., \& Istomo. (1993). Arahan Pemanfaatan Ekosistem Mangrove untuk Rekreasi. Bogor: IPB (Tidak di Publikasikan).

Masayoe, S. (2016). Perilaku Masyarakat Dalam Pengelolaan Kesehatan Lingkungan (Studi di Desa Segiguk sebagai Salah Satu Desa Penyangga Kawasan Hutan Suaka Margasatwa Gunung Raya Ogan Komering Ulu Selatan). Jurnal Penelitian Sains, 42-46. 
Muthmainnah, Irma, S., \& Fauziah. (2020). Analisis Kelayakan Potensi Ekowisata Hutan Mangrove di Dusun Matalalang Kecamatan Bontoharu Kepulauan Selayar. Jurnal Hutan dan Masyarakat, 106119.

Nining, I., \& Susmala, D. (2018). Strategi Pengembangan Objek Wisata Gua Batu Cermin di Tinjau Dari Aspek Lingkungan Geografis Di Kecamatan Komodo Kabupaten Manggarai Barat. Geodika, 22-28.

Putra, W. (2014). Kawasan Ekowisata Hutan Mangrove di Desa Kuala Karang Kabupaten Kubu Raya. Jurnal Online Mahasiswa Arsitektur, 41-55.

Ria, R. A., Linda, T., \& Suriyadi, S. (2021). Kajian Karakteristik Morfologi Pulau Lembeh Untuk Pengembangan Ekowisata. Jurnal Spasial, 209-217.

Risma, H. (2014). Keberagaman Vegetasi dan Satwa Liar Hutan Mangrove. Jurnal Bionature, 117-122.

Safuridar, \& Puti, A. (2020). Dampak Pengembangan Ekowisata Hutan Mangrove terhadap Sosial dan Ekonomi Masyarakat di Desa Kuala Langsa, Aceh. Jurnal Samudra Ekonomi dan Bisnis, 43-52.

Shinta, H. Y. (2017). Pengelolaan Ekowisata Mangrove Sebagai Penunjang Perekonomian Masyarakat Melalui Pendekatan Ekologi dan Sosial: Studi Kasus Mangrove Blok Bedul, Resort Gajakan Taman Nasional Alas Purwo Banyuwangi. Publishing Widyagama, 65-78.

Sihite. (2005). Pemberdayaan Mayarakat Pesisir. Jawa Tengah: Lembaga Swadaya Masyarakat.

Singarimbun, M., \& Sofian Effendi. (2002.). Metode Penelitian Survai. Jakarta: LP3ES.

Suhendang, E. (2002). Pengantar Ilmu Kebutanan. Bogor: Yayasan Penerbit Fakultas Kehutanan Institut Pertanian Bogor.

Suwarsih. (2013). Manfaat Hutan Mangrove Jenu Tuban Dari Sisi Penilaian Ekonomi. Jurnal Ekologia, 816.

Yati, A. (2014). Metodologi Penelitian Kualitatif Dalam Riset Keperawatan. Jakarta: PT Raja Grafindo Persada. 